\title{
Pengembangan Website Lembar Kerja Siswa Berbasis Penemuan Terbimbing Pada Materi Bangun Ruang Sisi Datar Kelas VIII
}

\author{
Defi Kamilia'), Baidowi' ${ }^{2)}$, dan Hapipi ${ }^{2)}$ \\ 1) Guru SMPN 6 Mataram, Kota Mataram \\ 2) Program Studi Pendidikan Matematika, FKIP Universitas Mataram, Kota Mataram \\ defi696kamilia@gmail.com
}

\begin{abstract}
The purpose of this research was to develop a student's worksheets website based on guided discovery on polyhedron concept of $8^{\text {th }}$ grade at MTsN. Student's worksheets website based on guided discovery was student's worksheets which arranged based on the phases of the guided discovery model, and presented in a website. This website created for local network. The purpose of developing this product was to resolve the weaknesses of printed student's worksheets and also the weaknesses of applying guided discovery models. The research methodology used in developing the product was 4D (Define, Design, Development, Dissemination). The technique of collecting data was using interview and questionnaire. The result of this research was a valid student's worksheets website based on guided discovery on polyhedron concept. This product has been declared valid with very good criteria, by two validators. Then, the valid product was being tested limitedly at MTsN to know student's response. The respondent sample was divided into two groups of student, the superior group and the regular group. The response of product usefulness from superior group had been examined as good. Therefore, the response from regular group was very good. Based on the results, the response of $8^{\text {th }}$ grade students (class VIII-2 and VIII-5) at MTsN, overall was good.
\end{abstract}

Keywords: Student's Worksheet, Website, Guided Discovery

\begin{abstract}
Abstrak
Tujuan penelitian ini adalah untuk mengembangkan website lembar kerja siswa (LKS) berbasis penemuan terbimbing pada materi bangun ruang sisi datar kelas VIII di. Website LKS berbasis penemuan terbimbing merupakan LKS yang disusun berdasarkan fase-fase pada model penemuan terbimbing, yang disajikan dalam sebuah website. Website ini dibuat untuk dapat diakses melalui jaringan lokal. Pengembangan produk ini bertujuan untuk mengatasi beberapa kelemahan dari LKS cetak serta kelemahan penerapan model penemuan terbimbing. Metodologi penelitian yang digunakan dalam mengembangan website LKS berbasis penemuan terbimbing adalah 4D (Define, Design, Development, Dissemination). Teknik pengumpulan data menggunakan wawancara dan kuisioner. Hasil penelitian ini adalah produk yang sudah valid berupa website lembar kerja siswa berbasis penemuan terbimbing pada materi bangun ruang sisi datar. Produk telah dinyatakan valid dengan kriteria sangat baik, oleh dua orang validator. Setelah dinyatakan valid, dilakukan uji coba terbatas untuk mengetahui respon siswa kelas VIII di MTsN sebagai pengguna akhir produk.
\end{abstract}


Sampel dari uji coba terbatas terdiri dari dua kelompok siswa, yakni siswa kelas unggulan dan kelas regular. Respon siswa unggulan terhadap penggunaan produk, dinilai baik. Adapun respon siswa regular, dinilai sangat baik. Berdasarkan hasil yang diperoleh diketahui bahwa respon siswa kelas VIII (kelas VIII-2 dan VIII-5) secara keseluruhan, adalah baik.

Kata Kunci: Lembar Kerja Siswa, Website, Penemuan Terbimbing

\section{PENDAHULUAN}

Berdasarkan hasil observasi di MTsN, diketahui bahwa salah satu media pembelajaran matematika yang digunakan adalah Lembar Kerja Siswa (LKS) yang disusun dalam bentuk buku paket, dan dikenal dengan buku LKS PR. Buku LKS tersebut, memuat ringkasan materi, latihan pemantapan pemahaman dan latihan soal. Buku LKS matematika kelas VIII di MTsN 1 Mataram tersebut, utamanya digunakan sebagai bahan ajar yang membantu guru dalam menjelaskan materi ajar. Hal ini tidak sesuai dengan peran LKS dalam pembelajaran (Anggraini, 2016), yakni meminimalkan peran pendidik dan lebih mengaktifkan peran peserta didik.

Berdasarkan hasil wawancara dengan Bapak Alfian, guru matematika di MTsN 1 Mataram, diketahui bahwa penggunaan media pembelajaran berupa LKS berbasis penemuan terbimbing, pernah dilakukan. LKS tersebut disusun oleh guru dengan tujuan untuk membantu siswa menemukan konsep pada materi teorema Pythagoras. Menurut beliau, proses pebelajaran dengan bantuan LKS berbasis penemuan terbimbing berjalan cukup efektif. Namun, terdapat beberapa siswa (kurang lebih 40\% dari jumlah siswa di kelas) yang kesulitan dalam memahami petunjuk LKS.

Berdasarkan hasil wawancara dengan Dimas, salah satu siswa kelas VIII di MTsN, kesulitan yang dialami saat mengerjakan LKS berbasis penemuan adalah kesulitan dalam memahami maksud dari petunjuk pada LKS. Siswa tidak dapat memahami langkah-langkah yang diberikan untuk membantu penemuan konsep. Akibatnya, siswa kesulitan menemukan konsep yang akan dipelajari. Terdapat beberapa penyebab munculnya kesulitan tersebut, di antaranya yakni siswa terbiasa mendengar penjelasan rinci dari guru sebelum mengerjakan tugas, lemahnya penguasaan materi pra-syarat serta minat baca siswa yang sangat kurang.

Internet sebagai salah satu produk dari perkembangan Teknologi Informasi dan Komunikasi (TIK) dapat digunakan untuk mendukung program pembelajaran. Internet dapat digunakan dalam pembelajaran secara terprogram, hal ini sering disebut dengan e-learning. Program e-learning dikemas dalam bentuk website yang dapat diakses oleh pengguna internet(Rusman, 2013). Penggunaan web untuk penyajian program $e$ learning dapat membantu menyediakan bahan ajar secara lengkap baik yang bersifat interaktif maupun non-interaktif. Penggunaan web juga memungkinkan tenaga pendidik untuk mendeteksi progress kegiatan siswa dalam pembelajaran, kemajuan belajar, skor hasil belajar dan lain-lain(Daryanto, 2016).

Berdasarkan hasil penelitian Krisantari(Paskalia, 2017) diketahui bahwa pengembangan LKS dengan model penemuan terbimbing berbasis web, dapat menjadi inovasi baru dan meningkatkan semangat belajar siswa. Berdasarkan penelitian tersebut, diketahui bahwa $97 \%$ dari subjek penelitian mengatakan LKS model penemuan terbimbing berbasis web dapat menjadi inovasi baru dalam pembelajaran. 
Selain itu, 66\% dari subjek penelitian mengatakan bahwa LKS tersebut dapat meningkatkan motivasi dan semangat siswa dalam mengikuti proses pembelajaran Geometri merupakan salah satu muatan materi matematika yang paling banyak

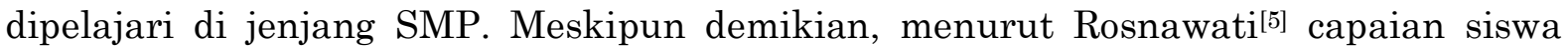
Indonesia pada TIMSS tahun 2011 untuk domain geometri masih tergolong rendah. Menurut guru matematika di MTsN, domain geometri merupakan domain yang cukup sulit untuk dijelaskan guru maupun dipahami siswa. Penyampaian materi geometri tidak cukup hanya dengan bantuan LKS PR, tetapi dibutuhkan media yang bisa menampilkan ilustrasi yang lebih jelas dan mudah dipahami siswa.

Penerapan kurikulum 2013 bertujuan untuk menghadirkan proses pembelajaran berbasis proses. Model penemuan terbimbing merupakan salah satu model pembelajaran yang dapat menghadirkan pembelajaran berbasis proses. Untuk mendukung kegiatan pembelajaran dengan model penemuan terbimbing, diperlukan media pembelajaran yang sesuai. Pemanfaatan teknologi dapat memfasilitasi pengembangan media pembelajaran yang dapat mengatasi kesulitan guru maupun siswa dalam proses pembelajaran. Oleh karena itu, diperlukan pengembangan website lembar kerja siswa berbasis penemuan terbimbing pada materi bangun ruang sisi datar kelas VIII di MTsN.

Rumusan masalah dalam penelitian ini adalah Bagaimana pengembangan website lembar kerja siswa berbasis penemuan terbimbing pada materi bangun ruang sisi datar kelas VIII di MTSN? Oleh karena itu, tujuan penelitian ini adalah untuk mengembangkan website lembar kerja siswa berbasis penemuan terbimbing pada materi bangun ruang sisi datar kelas VIII di MTSN.

\section{METODE PENELITIAN}

Pengembangan website lembar kerja siswa berbasis penemuan terbimbing bertujuan untuk menghasilkan produk LKS yang disajikan dalam bentuk website dan disusun berdasarkan langkah-langkah metode penemuan terbimbing. Produk yang akan dihasilkan merupakan pengembangan dari LKS kelas VIII di MTsN, khususnya materi bangun ruang sisi datar. Oleh karena itu, penelitian ini merupakan penelitian dan pengembangan (Research and Development), yang bertujuan untuk menghasilkan produk.

Langkah-langkah penelitian dan pengembangan disingkat dengan 4D yang merupakan singkatan dari Define, Design, Development and Disseminatio (Thiagarajan,1974). Tahap define berisi kegiatan untuk menetapkan produk apa yang akan dikembangkan, beserta spesifikasinya. Tahap design, berisi kegiatan untuk membuat rancangan terhadap produk yang telah ditetapkan. Tahap development, berisi kegiatan pengembangan produk dan menguji validitasnya. Tahap dissemination berisi kegiatan menyebarluaskan produk yang telah diuji untuk dimanfaatkan orang lain(Sugiyono, 2017).

\section{HASIL DAN PEMBAHASAN}

\section{A. Hasil}

Tujuan penelitian ini adalah untuk mengembangkan website lembar kerja siswa berbasis penemuan terbimbing pada materi bangun ruang sisi datar kelas VIII di MTsN 
1 Mataram. Hasil penelitian ini adalah website lembar kerja siswa berbasis penemuan terbimbing yang telah divalidasi dan diuji coba dalam skala terbatas. Pengembangan website ini didasarkan pada hasil dari tahap define. Berdasarkan hasil tahap define diketahui bahwa model pembelajaran yang sering diterapkan di MTsN 1 Mataram adalah model pembelajaran langsung dengan metode ceramah, hal ini menunjukkan pembelajaran yang dilaksanakan belum sesuai dengan prinsip pembelajaran dalam kurikulum 2013. Selain itu, bahan ajar yang digunakan guru berupa buku Lembar Kerja Siswa (LKS) kurang dapat mendukung pembelajaran berbasis proses.

Berdasarkan hasil dari tahap define, diketahui bahwa terdapat potensi siswa untuk dapat mengikuti pembelajaran berbasis proses dengan penguatan pendekatan ilmiah. Hal ini ditunjukkan dari efektifitas pembelajaran dengan model penemuan terbimbing yang pernah diterapkan oleh guru di MTsN 1 Mataram. Meskipun demikian, terdapat beberapa kendala yang dialami guru maupun siswa dalam pembelajaran tersebut. Guru merasa kesulitan untuk memberikan bimbingan kepada seluruh siswa dalam menemukan konsep. Hal ini disebabkan oleh jumlah siswa yang relative banyak. Adapun siswa merasa kesulitan memahami petunjuk, dikarenakan siswa kurang menguasai materi pra-syarat.

Tahap design dilaksanakan dengan berdasarkan pada hasil tahap define. Pada tahap ini, telah disusun rancangan awal dari website lembar kerja siswa berbasis penemuan terbimbing. Rancangan awal dari produk ini ditunjukkan pada Tabel 1.

Tabel 1 Rancangan Website Lembar Kerja Siswa Berbasis Penemuan Terbimbing Berdasarkan Fase Penerapan Model Penemuan Terbimbing

\begin{tabular}{cl}
\hline Fase & \multicolumn{1}{c}{ Representasi pada website lembar kerja siswa } \\
\hline Pendahuluan & $\begin{array}{l}\text { Menarik perhatian siswa dengan menampilkan animasi baik } \\
\text { dalam bentuk gambar atapun video. } \\
\text { Menetapkan fokus pembelajaran dengan menyampaikan } \\
\text { kompetensi dasar dan tujuan pembelajaran yang akan } \\
\text { dicapai melalui video dan gambar. }\end{array}$ \\
\hline Terbuka & $\begin{array}{l}\text { Memberikan beberapa contoh yang dapat diamati siswa untuk } \\
\text { mengumpulkan informasi melalui video. }\end{array}$ \\
\hline Konvergen & $\begin{array}{l}\text { Menuntun siswa menemukan konsep dengan pertanyaan- } \\
\text { pertanyaan spesifik terkait dengan contoh yang ditampilkan. }\end{array}$ \\
\hline $\begin{array}{c}\text { Penutup dan } \\
\text { Penerapan }\end{array}$ & $\begin{array}{l}\text { Menuntun siswa untuk membuat kesimpulan dengan bantuan } \\
\text { gambar dan pertanyaan ataupun pernyataan. } \\
\text { Memfasilitasi siswa untuk menerapkan konsep yang } \\
\text { ditemukan dengan menyediakan latihan soal. }\end{array}$
\end{tabular}

Pada tahap development, diperoleh hasil berupa produk yang telah valid serta respon siswa terhadap penggunaan produk. Data hasil validasi ahli terhadap produk, dapat dilihat pada Tabel 2.

Tabel 2 Hasil Validasi Ahli

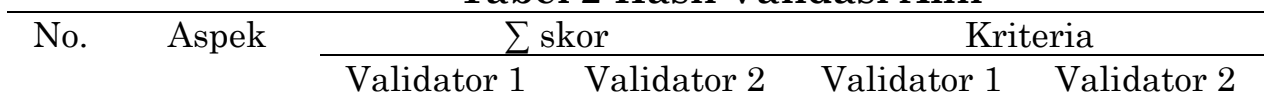




\begin{tabular}{clcccc}
\hline 1. & Penyajian & 43 & 49 & $\begin{array}{c}\text { Sangat } \\
\text { Baik }\end{array}$ & $\begin{array}{c}\text { Sangat } \\
\text { Baik }\end{array}$ \\
\hline 2. & Isi & 19 & 19 & $\begin{array}{c}\text { Sangat } \\
\text { Baik }\end{array}$ & $\begin{array}{c}\text { Sangat } \\
\text { Baik }\end{array}$ \\
\hline 3. & Tampilan & 14 & 13 & $\begin{array}{c}\text { Sangat } \\
\text { Baik }\end{array}$ & $\begin{array}{c}\text { Sangat } \\
\text { Baik }\end{array}$ \\
\hline
\end{tabular}

Setelah dilakukan validasi ahli, kemudian dilakukan beberapa revisi sesuai dengan saran dari validator. Setelah revisi produk, dilakukan uji coba dalam skala terbatas. Hasil uji coba terbatas dapat dilihat pada Tabel 3

\section{Tabel 3 Data Respon Siswa Kelas VIII-2 dan VIII-5 Terhadap Website Lembar Kerja Siswa Berbasis Penemuan Terbimbing}

\begin{tabular}{ccc}
\hline Tingkat Kemampuan Siswa & VIII-2 & VIII-5 \\
\hline Tinggi & Baik & Sangat Baik \\
\hline Sedang & Baik & Sangat Baik \\
\hline Rendah & Baik & Baik \\
\hline
\end{tabular}

Berdasarkan data respon siswa pada Tabel 3 diketahui bahwa rata-rata respon siswa dengan kemampuan berbeda-beda, setelah menggunakan website lembar kerja siswa berbasis penemuan terbimbing adalah baik. Selain ditinjau dari tingkat kemampuannya, respon siswa juga ditinjau dari sub-materi pada materi bangun ruang sisi datar. Respon siswa ditinjau dari sub-materi yang dikerjakan setiap siswa, dapat dilihat pada Tabel 4.

\section{Tabel 4 Data Respon Siswa Kelas VIII-2 Dan VIII-5 Terhadap Website Lembar Kerja Siswa Berbasis Penemuan Terbimbing Ditinjau dari Sub- Materi Yang Dikerjakan}

\begin{tabular}{ccc}
\hline Sub-Materi yang Dikerjakan & Skor Rata-Rata & Kualifikasi \\
\hline Balok & 4,1 & Baik \\
\hline Kubus & 4,2 & Baik \\
\hline Prisma & 4,1 & Baik \\
\hline Limas & 4,1 & Baik \\
\hline
\end{tabular}

Setelah dilakukan uji coba, kemudian dilakukan penyebarluasan produk website lembar kerja siswa berbasis penemuan terbimbing yang dilaksanakan di MTsN, dengan memberikan guru dan siswa menggunakannya serta menjadikan komputer server di sekolah menjadi server dari website ini. Sehingga guru matematika di MTsN dapat menggunakannya dalam pembelajaran matematika kelas VIII pada materi bangun ruang sisi datar.

\section{B. Pembahasan}

Berdasarkan data hasil penelitian yang diperoleh dari setiap tahapan penelitian (tahap define, tahap design, tahap development, dan tahap disseminate), telah dikembangkan website lembar kerja siswa berbasis penemuan terbimbing pada materi bangun ruang sisi datar kelas VIII di MTsN 1 Mataram yang dapat digunakan dalam pembelajaran. 
Hal tersebut ditunjukkan berdasarkan skor rata-rata dari data hasil validasi ahli, sebesar 4,6 dengan kualifikasi sangat baik serta skor rata-rata dari data respon siswa, sebesar 4,1 dengan kualifikasi baik. Hal ini menunjukkan bahwa produk yang dikembangkan memiliki kualitas yang baik dan dapat digunakan dalam pembelajaran.

Website lembar kerja siswa berbasis penemuan terbimbing merupakan Lembar Kerja Siswa (LKS) yang disajikan dalam bentuk website interaktif. Penyajian isi dari website disusun berdasarkan fase-fase pada model penemuan terbimbing. Website lembar kerja siswa juga didukung dengan ilustrasi dalam bentuk gambar dan video. Produk ini dikembangkan dengan tujuan agar dapat membantu guru untuk menghadirkan pembelajaran berbasis proses, yang berpusat pada siswa, dengan bantuan beragam sumber belajar berupa gambar, audio dan video pada website.

Website lembar kerja siswa berbasis penemuan terbimbing, dirancang untuk dapat menggantikan fungsi LKS cetak dan mengatasi kelemahannya. Menurut Rosidi ${ }^{[8]}$ fungsi LKS yaitu memudahkan siswa dalam memahami materi pelajaran. Berdasarkan hasil uji coba terbatas yang dilakukan terhadap 24 siswa kelas VIII di MTsN 1 Mataram, diketahui bahwa respon siswa terhadap penggunaan website lembar kerja siswa ditinjau dari fungsinya, memperoleh kualifikasi baik dengan skor rata-rata 4,1. Aspek fungsi dari produk ini dinilai melalui butir pernyataan no. 1, 2, 3 dan 5 pada lembar respon siswa terhadap penggunaan website lembar kerja siswa berbasis penemuan terbimbing (Skor setiap butir terlampir). Hal ini menunjukkan bahwa produk yang dikembangkan mampu menggantikan fungsi LKS cetak dengan baik.

Kelemahan dari LKS cetak merupakan salah satu alasan pengembangan website lembar kerja siswa berbasis penemuan terbimbing. Menurut Yusuf ${ }^{[9]}$ kelemahan LKS cetak adalah dari segi tampilan, isi dan kepraktisannya. Tampilan dari LKS tidak dapat menarik perhatian siswa, mengingat minat baca dari siswa Indonesia tergolong rendah. Isi dari LKS juga belum dapat membuat siswa aktif dalam proses pembelajaran. Adapun bentuk LKS sebagai media cetak masih tergolong kurang praktis, karena masih bergantung pada penggunaan kertas dan harus dibawa pada saat penggunaannya.

Kemampuan produk dalam mengatasi kelemahan LKS cetak menurut siswa sebagai pengguna diukur melalui butir pernyataan no. 8, 9 dan 10 pada lembar respon siswa. Rata-rata skor yang diperoleh adalah 4,3 dengan kualifikasi sangat baik. Hal ini menunjukkan bahwa penggunaan website lembar kerja siswa berbasis penemuan terbimbing mampu mengatasi kelemahan yang terdapat pada LKS cetak dengan baik.

Berdasarkan hasil penelitian pada tahap define diketahui bahwa LKS cetak yang digunakan di MTsN, kurang dapat membantu siswa untuk menemukan konsep. Hal ini menyebabkan guru kesulitan untuk menerapkan model pembelajaran yang dapat menghasilkan pembelajaran berbasis proses dengan penguatan pendekatan ilmiah. Oleh karena itu, produk ini dikembangkan untuk membantu guru maupun siswa dalam menghadirkan pembelajaran dengan model penemuan terbimbing.

Website lembar kerja siswa berbasis penemuan terbimbing disajikan dengan berdasarkan pada fase-fase model penemuan terbimbing. Berdasarkan hasil validasi ahli terhadap kesesuaian penyajian isi produk dengan fase-fase tersebut, produk ini 
mampu menampilkan representasi dari setiap fase dengan sangat baik. Hal ini ditunjukkan dari rata-rata skor validasi produk, yakni 4,6.

Berdasarkan hasil validasi ahli berkaitan dengan kemampuan produk dalam mengatasi kelemahan penerapan model penemuan terbimbing, diketahui bahwa produk dapat mengatasi kelemahan tersebut dengan sangat baik. Hal ini ditunjukkan dari skor ratarata yang diperoleh untuk butir pernyataan no. 5 dan 7 yakni 4,75. Selain itu respon siswa juga menunjukkan hal yang sama, yakni skor rata-rata yang diperoleh pada butir pernyataan no. 6 dan 11 pada lembar respon siswa, sebesar 4,2.

Website lembar kerja siswa berbasis penemuan terbimbing, selain dikembangkan berdasarkan pada fase model penemuan terbimbing, juga memperhatikan syarat-syarat yang harus dipenuhi dalam penyusunan LKS sebagai media pembelajaran, yakni syarat didaktik, syarat konstruksi dan syarat teknis. syarat didaktik mengatur tentang penggunaan LKS yang bersifat universal, artinya dapat digunakan siswa dengan kemampuan yang berbeda-beda(Solfitri, 2017). Syarat konstruksi adalah syarat-syarat yang berkenaan dengan penggunaan bahasa, susunan kalimat, kosakata, tingkat kesukaran dan kejelasan petunjuk. Adapun syarat teknis yaitu syarat yang menekankan pada aspek penyajian LKS yang berupa tulisan, gambar dan tampilan.

Berdasarkan hasil validasi ahli terhadap produk yang dikembangkan, diketahui bahwa produk ini telah memenuhi syarat-syarat penyusunan LKS. Hal ini ditunjukkan dari skor rata-rata yang diperoleh untuk butir pernyataan no. 11, 13, 14, 15, dan 16 yakni 4,8 dengan kualifikasi sangat baik. Selain itu, berdasarkan data hasil respon siswa ditinjau dari tingkat kemampuannya, diketahui bahwa respon siswa terhadap penggunaan produk adalah baik, dengan skor rata-rata 4,1 , sehingga syarat didaktik terpenuhi. Adapun syarat konstruksi dan teknis berdasarkan respon siswa juga terpenuhi, ditunjukkan melalui skor yang diperoleh pada butir pernyataan no. 4, 10 dan 11 , dengan rata-rata skor 4,3 .

Website lembar kerja siswa berbasis penemuan terbimbing sebagai media pembelajaran berbasis website harus memenuhi indikator website yang baik. Menurut Hariyanto dkk.[11] kualitas yang dimiliki oleh sebuah website dapat diukur berdasarkan tiga dimensi penilaian, yaitu kegunaan (usability), kualitas informasi (information quality), dan interaksi layanan (service interaction). Berdasarkan hasil validasi ahli terhadap produk yang dikembangkan ditinjau dari kualitas website, diketahui bahwa kualitas website sudah sangat baik. Hal ini ditunjukkan dari skor rata-rata yang diperoleh dari setiap butir pernyataan pada lembar validasi yakni sebesar 4,6. Adapun berdasarkan respon siswa terhadap penggunaan produk, diketahui bahwa kualitas website sudah baik. Hal ini ditunjukkan dari skor rata-rata yang diperoleh dari setiap butir pernyataan pada lembar respon siswa yakni sebesar 4,1 .

Berdasarkan uji coba terbatas yang dilaksanakan untuk mengetahui respon siswa kelas VIII di MTsN, diketahui bahwa respon siswa kelas regular lebih baik daripada siswa kelas unggulan. Hal ini ditunjukkan dari skor rata-rata yang diperoleh dari data hasil respon siswa kelas unggulan sebesar 3,9 dengan kualifikasi baik. Adapun skor rata-rata yang diperoleh dari data hasil respon siswa kelas reguler sebesar 4,4 dengan kualifikasi sangat baik Berdasarkan hasil pengamatan terhadap kegiatan uji coba yang dilaksanakan terhadap 12 siswa kelas unggulan, ketika menggunakan website lembar kerja siswa berbasis penemuan terbimbing, siswa kurang fokus dalam membaca petunjuk dan suasana kelas sedikit ribut. Adapun saat uji coba produk terhadap 12 siswa kelas regular, siswa sangat memperhatikan petunjuk yang disediakan dan mencatat penjelasan yang disampaikan pada video yang tersedia.

Berdasarkan data hasil validasi ahli terhadap website lembar kerja siswa berbasis penemuan terbimbing sebagai produk yang dikembangkan, penelitian ini telah 
menghasilkan produk yang valid dengan kualifikasi sangat baik. Berdasarkan data hasil respon siswa sebagai pengguna dari produk yang dikembangkan, penelitian ini berhasil menghasilkan website lembar kerja siswa berbasis penemuan terbimbing pada materi bangun ruang sisi datar kelas VIII di MTsN yang dapat digunakan dalam pembelajaran. Hal ini sejalan dengan penelitian hasil penelitian terhadap penggunaan LKS Interaktif berbasis komputer diketahui respon siswa terhadap penggunaan LKS Interaktif pada pembelajaran matematika, dinilai baik(Muhamad, 2010).

\section{KESIMPULAN}

Berdasarkan hasil penelitian, analisis data dan pembahasan, dapat disimpulkan bahwa produk yang dikembangkan telah memenuhi kriteria sangat baik dan dapat dikatakan valid. Penyajian produk (website lembar kerja siswa berbasis penemuan terbimbing), dirancang sesuai dengan fase-fase pada model penemuan terbimbing. Isi dari website lembar kerja siswa berbasis penemuan terbembing, dirancang sesuai dengan syaratsyarat penyusunan lembar kerja siswa yaitu didaktik, kontruksi dan teknis. Adapun kualitas tampilan website dinilai baik dengan skor 4,2 (kategori baik untuk interval: $3,40<$ skor $\leq 4,21$ ) berdasarkan penilaian siswa sebagai pengguna akhir.

\section{DAFTAR PUSTAKA}

Anggraini, Rivalia, dkk. (2016). Pengembangan Lembar Kerja Siswa (LKS) Berbasis Keterampilan Proses di SMAN 4 Jember. Jurnal Pembelajaran Fisika. Vol.4 (4): $350-356$.

Daryanto. 2016. Media Pembelajaran: Perannya Sangat Penting Dalam Mencapai Tujuan Pembelajaran. Yogyakarta: Gava Media.

Hariyanto, Y dkk. (2018). Analisis Kualitas Website Universitas dengan Metode Webqual. Jurnal Teknik dan Ilmu Komputer Vol. 7(26): 339-348

Irsad, R. (2016). Pengembangan Lembar Kegiatan Siswa Berorientasi Pembelajaran Penemuan Terbimbing (Guided Discovery Learning) untuk Melatihkan Keterampilan Proses Sains. Jurnal Pena Sains Vol. 3(1): 55-63.

Krisantari, Paskalia. (2017). Pengembangan Lembar Kerja Siswa Model Penemuan Terbimbing Berbasis Web Pada Pokok Bahasan Persamaan Lingkaran Kelas XI SMK Negeri 2 Depok Yogyakarta. Yogyakarta: Universitas Sanata Dharma.

Muhamad,Y. (2010). Peningkatan Hasil Belajar Matematika Siswa Melalui Lembar Kerja Siswa (LKS) Interaktif Berbasis Komputer di SMA Muhammadiyah Pelmbang. Jurnal Pendidikan Matematika Vol. 4 (2): 34 - 44.

Rosnawati, R. (2013). Kemampuan Penalaran Matematika Siswa SMP Indonesia Pada TIMSS 2011. Yogyakarta: Prosiding Seminar Nasional Penelitian, Pendidikan dan Penerapan MIPA, Fakultas MIPA Universitas Negeri Yogyakarta.

Rusman. (2013). Model-Model Pembelajaran: Mengembangkan Profesionalisme Guru. Depok: PT RAJAGRAFINDO PERSADA.

Sugiyono. 2017. Metode Penelitian dan Pengembangan. Bandung: CV ALFABETA.

Thiagarajan, S., Semmel, D. S. \& Semmel, M. I. (1974). Intructional Development for Training Teachers of Exceptional Children. Mineapolis, Minnesota: Leadership Training Institute/ Special Education, University of Minnesota. 
Titi, S. (2017). Pengembangan Perangkat Pembelajaran Matematika Berbasis Kurikulum 2013 Pada Materi Bangun Ruang Sisi Datar dan Lingkaran Untuk Siswa Kelas VIII Tingkat SMP/MTS. Jurnal EduMath Vol. 4(1):59-66. 